\title{
Front Matter: Volume 11230
}

, "Front Matter: Volume 11230," Proc. SPIE 11230, Optics and Biophotonics in Low-Resource Settings VI, 1123001 (13 March 2020); doi:

$10.1117 / 12.2569501$

SPIE. Event: SPIE BiOS, 2020, San Francisco, California, United States 


\section{PROGRESS IN BIOMEDICAL OPTICS AND IMAGING}

\section{Optics and Biophotonics in Low-Resource Settings VI}

David Levitz Aydogan Ozcan

Editors

1-2 February 2020

San Francisco, California, United States

Sponsored and Published by

SPIE 
The papers in this volume were part of the technical conference cited on the cover and title page. Papers were selected and subject to review by the editors and conference program committee. Some conference presentations may not be available for publication. Additional papers and presentation recordings may be available online in the SPIE Digital Library at SPIEDigitalLibrary.org.

The papers reflect the work and thoughts of the authors and are published herein as submitted. The publisher is not responsible for the validity of the information or for any outcomes resulting from reliance thereon.

Please use the following format to cite material from these proceedings:

Author(s), "Title of Paper," in Optics and Biophotonics in Low-Resource Settings Vl, edited by David Levitz, Aydogan Ozcan, Proceedings of SPIE Vol. 11230 (SPIE, Bellingham, WA, 2020) Seven-digit Article CID Number.

ISSN: 1605-7422

ISSN: 2410-9045 (electronic)

ISBN: 9781510632233

ISBN: 9781510632240 (electronic)

Published by

SPIE

P.O. Box 10, Bellingham, Washington 98227-0010 USA

Telephone +1 3606763290 (Pacific Time) · Fax +1 3606471445

SPIE.org

Copyright (c) 2020, Society of Photo-Optical Instrumentation Engineers.

Copying of material in this book for internal or personal use, or for the internal or personal use of specific clients, beyond the fair use provisions granted by the U.S. Copyright Law is authorized by SPIE subject to payment of copying fees. The Transactional Reporting Service base fee for this volume is $\$ 21.00$ per article (or portion thereof), which should be paid directly to the Copyright Clearance Center (CCC), 222 Rosewood Drive, Danvers, MA 01923. Payment may also be made electronically through CCC Online at copyright.com. Other copying for republication, resale, advertising or promotion, or any form of systematic or multiple reproduction of any material in this book is prohibited except with permission in writing from the publisher. The CCC fee code is $1605-$ $7422 / 20 / \$ 21.00$.

Printed in the United States of America by Curran Associates, Inc., under license from SPIE.

Publication of record for individual papers is online in the SPIE Digital Library.

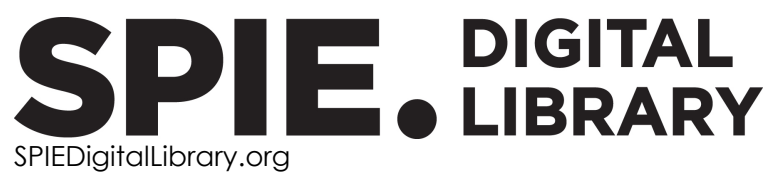

Paper Numbering: Proceedings of SPIE follow an e-First publication model. A unique citation identifier (CID) number is assigned to each article at the time of publication. Utilization of CIDs allows articles to be fully citable as soon as they are published online, and connects the same identifier to all online and print versions of the publication. SPIE uses a seven-digit CID article numbering system structured as follows:

- The first five digits correspond to the SPIE volume number.

- The last two digits indicate publication order within the volume using a Base 36 numbering system employing both numerals and letters. These two-number sets start with $00,01,02,03,04$, 05, 06, 07, 08, 09, 0A, OB ... 0Z, followed by 10-1Z, 20-2Z, etc. The CID Number appears on each page of the manuscript. 


\title{
Contents
}

\author{
$\checkmark \quad$ Authors \\ vii Conference Committee
}

OPTICS FOR LOW RESOURCE SETTINGS

1123005 Low cost microscope for malarial parasitemia quantification in microfluidically generated blood smears [11230-4]

\section{MOBILE MICROSCOPY, SENSING AND DIAGNOSTICS TECHNOLOGIES}

$112300 \mathrm{~A} \quad$ Field-portable multi-modal chip-based fluorescence, bright field and quantitative phase microscopy using smartphone detecting system [1 1230-9]

EMERGING PLATFORMS FOR IMAGING, SENSING AND DIAGNOSTICS

$11230 \mathrm{Ol} \quad$ Optical imaging using an oil droplet and a cellphone camera [11230-19]

11230 OK Light-assisted drying (LAD) for anhydrous preservation of biologics: using Raman spectroscopy to assess the uniformity of drying in processed samples [11230-21]

$11230 \mathrm{OL} \quad$ Visual field self-evaluation by free-focus retinal-scanning laser display technology [11230-22]

$11230 \mathrm{OM}$ Thin-film plastics used in microfluidic channels for microscopy imaging in low resource settings [11230-23]

\section{POSTER SESSION}

11230 oY A portable device using a single-board computer for white light and fluorescence widefield images [11230-33]

1123012 Multi-spectral vascular oximetry of rat dorsal spinal cord [1 1230-38] 
Proc. of SPIE Vol. $112301123001-4$ Downloaded From: https://www.spiedigitallibrary.org/conference-proceedings-of-spie on 26 Apr 2023
Terms of Use: https://www.spiedigitallibrary.org/terms-of-use 


\title{
Authors
}

Numbers in the index correspond to the last two digits of the seven-digit citation identifier (CID) article numbering system used in Proceedings of SPIE. The first five digits reflect the volume number. Base 36 numbering is employed for the last two digits and indicates the order of articles within the volume. Numbers start with 00, 01, 02, 03, 04, 05, 06, 07, 08, 09, OA, OB...0Z, followed by 10-1Z, 20-2Z, etc.

\author{
Alqashmi, Mohamed, 01 \\ Ashikaga, Hideaki, OL \\ Branan, Kimberly, OM \\ Chianfrone, Daniel José, OY \\ Cooper, Jonathan M., 12 \\ Coté, Gerard L., 05, OM \\ Dogbevi, Kokou S., 05, OM \\ Dubey, Vishesh Kumar, OA \\ Feitosa, Patrick Oliveira, OY \\ Furr, Daniel P., OK \\ Garcia, Marlon Rodrigues, OY \\ Gordon, Paul, 05, 0M \\ Harvey, Andrew R., 12 \\ $\mathrm{Hu}$, Ying S., Ol \\ Jing, Haoran, 0 I \\ Kageyama, Takeo, OL \\ Kiefer, Kevin, 05 \\ Konda, Pavan C., 12 \\ McKeough, Riley Q., OK \\ Mehta, Dalip Singh, OA \\ Mertens-Talcott, Susanne U., 05 \\ Miyauchi, Hironori, OL \\ Morino, Seiji, OL \\ Motaghian, Sara, 12 \\ Ochoa-Gutierrez, Victor, 12 \\ Pratavieira, Sebastião, OY \\ Reboud, Julien, 12 \\ Saito, Kazutaka, OL \\ Saxena, Anuj, OA \\ Singh, Veena, OA \\ Sugawara, Mitsuru, OL \\ Suzuki, Makoto, OL \\ Szydlowski, Nicole Anna, 01 \\ Tayal, Shilpa, OA \\ Trammell, Susan R., OK \\ Yasui, Kenji, OL \\ Zanchin, Anderson Luiz, OY \\ Zhang, Fan, OK \\ Zhang, Yong, OK
}


Proc. of SPIE Vol. 11230 1123001-6 Downloaded From: https://www.spiedigitallibrary.org/conference-proceedings-of-spie on 26 Apr 2023
Terms of Use: https://www.spiedigitallibrary.org/terms-of-use 


\section{Conference Committee}

Symposium Chairs

Jennifer K. Barton, The University of Arizona (United States)

Wolfgang Drexler, Medizinische Universität Wien (Austria)

Program Track Chairs

Tuan Vo-Dinh, Fitzpatrick Institute for Photonics, Duke University (United States)

Anita Mahadevan-Jansen, Vanderbilt University (United States)

Conference Chairs

David Levitz, MobileODT Ltd. (Israel)

Aydogan Ozcan, University of California, Los Angeles (United States)

Conference Program Committee

David Erickson, Cornell University (United States)

Gerard L. Coté, Texas A\&M University (United States)

Wolfgang Drexler, Medizinische Universität Wien (Austria)

Matthew D. Keller, Intellectual Ventures Laboratory (United States)

Avi Rasooly, National Institutes of Health (United States)

Anita Mahadevan-Jansen, Vanderbilt University (United States)

Chetan A. Patil, Temple University (United States)

Eric A. Swanson, Acacia Communications, Inc. (United States)

Sebastian Wachsmann-Hogiu, McGill University (Canada)

Ian M. White, University of Maryland, College Park (United States)

\section{Session Chairs}

1 Optics for Low Resource Settings

Aniruddha Ray, The University of Toledo (United States)

2 Mobile Microscopy, Sensing and Diagnostics Technologies

Gerard L. Coté, Texas A\&M University (United States)

3 Machine Learning-enabled Microscopy and Sensing I

Hatice Ceylan Koydemir, University of California, Los Angeles (United States)

4 Advances in Optical Coherence Tomography and Microscopy David Levitz, MobileODT Ltd. (Israel) 
5 Emerging Platforms for Imaging, Sensing and Diagnostics Jessica C. Ramella-Roman, Florida International University (United States)

$6 \quad$ Sensing Technologies for Low-Resource Settings

Zachary Scott Ballard, University of California, Los Angeles (United States)

7 Machine Learning-enabled Microscopy and Sensing II

David Levitz, MobileODT Ltd. (Israel) 